\title{
Feeding of Cabrera Vole in West-Central Spain
}

POKARM MICROTUS CABRERAE W ZACHODNIO-SRODKOWEJ HISZPANII

\author{
R. C. SORIGUER \& J. A. AMAT
}

Soriguer R. C. \& Amat J. A., 1988: Feeding of Cabrera vole in Westcentral Spain. Acta theriol., 33, 42: 589-593. [With 2 Tables]

The Cabrera vole (Microtus cabrerae Tomas, 1906) is an endemic and endangered species of the Iberian Peninsula. The voles inhabited "juncales", small patches of sedge-rushes and grasses (usually less than $250 \mathrm{~m}^{2}$ in area). The feeding of Cabrera vole was studied through faecal pellet analysis. The voles consumed mainly grasses and sedgerushes (over $60 \%$ of the diet). Both plant taxon were the main items consumed all year round. Finally, the role of the habitat stability was discussed in relation to the species conservation.

[Estacion Biológica de Doñana, Unidad de Ecologia y Etologia, Apdo 1056, Sevilla 41013, Epain].

\section{INTRODUCTION}

Cabrera vole (Microtus cabrerae Thomas, 1906) is a species endemic of the Iberian Peninsula. While some aspects of its life history are well known (zoogeography, taxonomy and biometry), many others (biology, ecology and population dynamics) are still virtually unknown (Ayarzaguena et al., 1975, 1976; Niethammer et al., 1964; Vericad, 1970, 1971).

In addition, $M$. cabrerae is an endangered species. It has disappeared from many localities where it was present only 10 years ago. Agricultural development (land and water management) and overgrazing are the main human activities related with the species habitat destruction. In this paper we described the feeding habits of the Cabrera vole in Westcentral Spain.

\section{MATERIAL AND METHODS}

Faecal pellets of $\boldsymbol{M}$. cabrerae were collected in two localities of West-central Spain. At Moraleja, Cáceres (LOCI), the samples were taken in November 1979 and May, August and December 1980. Puerto Perales, Salamanca (LOC2) was sampled in May 1982. The localities were less than $30 \mathrm{~km}$ apart.

In both localities the voles inhabited "juncales" which are small herbaceous patches, generally less than $250 \mathrm{~m}^{2}$, with rushes, sedges, and grasses as dominant plants. LOC1 is very close to the Arrago River forest gallery and the patches are surrounded by grassland. In LOC2 the vegetation patches were surrounded 
by irrigated grassland. In both localities the water level was very high (in LOC1 due to natural water upwelling and LOC2 due to irrigation).

Faecal pellets collected on the vole runways were dried at $40^{\circ} \mathrm{C}$ until constant weight. Previous to laboratory analysis, pellets were milled and homogenized through a mesh size of $0.75 \mathrm{~mm}$. The contents of at least 30 pellets were chemically treated according to Baumgartner and Martin (1939) and the fragments identified using microscopic preparations taken from a reference collection (Dusi, 1949; Hansson, 1970; Williams, 1962). For each sample, four slides of faecal fragments were mounted and microscopically examined at $125 \times$. The relative frequencies of occurrence of the different plant species in 200 microscope fields per sample (four subsamples of $\mathbf{5 0}$ fields) were transformed into the relative densities using the Fracker and Brischle (1944) table. Following the method of Reichman (1975), relative densities were expressed as a percentage of the total diet.

\subsection{Nutritional Analysis of the Main Items in the Diet of the Voles}

Nutritional analysis was done by infrared spectrophotometry and standard methods (Dr. Garcia Criado Laboratory, CEBA, C.S.I.C., Salamanca). Twenty four parameters were analyzed but only five are presented in this paper, for facilitating comparisons with previous published data. The following parameters were considered in this study: dry matter digestibility (DMD), protein (PROT), calcium (Ca), phosphorus (P) and sodium (Na). In addition we included the recommended nutrient content (RNC) in the vole's diet (Batzli, 1985). We also analyzed by qualitative analysis (Cabo \& Pardo, 1974; Dominguez, 1973) the following secondary compounds: saponins (haemolysis and foams test), tannins (gelatin and ferric chloride test), alkaloids (chromatography, Mayer and Dragendorf tests) and cyanogenic compounds (sodium picrate test).

\section{RESULTS}

\subsection{General Description of the Diet}

Plant remains were the main component of the diet of $M$. cabrerae at both study localities (Table 1). Leaves, stems and seeds of grasses were the main items. More than $58 \%$ of the diet was composed of grasses. Unfortunately only $13 \%$ of the remains could be identified as to genus. The identified grasses included the genera Bromus $(21.2 \%)$, Poa $(0.7 \%)$, Vulpia (6.2\%), Briza (24.2\%), and Avena (3.8\%).

The second important component in the diet were sedges and rushes (Table 1). This component was important because it was present in the diet throughout the year and contributed over $7 \%$ of the total diet. Holoschoenus and Juncus were the dominant plant genera. It was not possible to identify the different species of sedges and rushes present in the diet due to morphological similarity and the very small size of plant remains. 
The percentage of the animal component was very low (less than $3 \%$ ). Insect fragments were the most representative item.

\subsection{Seasonal and Local Variation in the Diet}

Grasses and sedges-rushes were the dominant food items, although their specific identity changed between months (Table 1).

The feeding of $M$. cabrerae in two localities of West-central Spain and in the same month can be observed in Table 1. Grasses, and sedgesrushes constituted $78.8 \%$ and $76.8 \%$ of the diet in LOC1 and LOC2, respectively. The main difference observed between the localities was the substitution of 3romus sp. (21.2\%) in LOC1 by Briza sp. (24.2) in LOC2. The final result appears to be the same: similar percentage of grasses in the diet.

\subsection{Nutritional Contents of the Main Items in the Diet}

In general the mean values of the nutritional contents for the main items in the voles diet fit quite well to the recommended nutrient content of the diet of the vole according to Batzli (1985) (Table 2). The differences between requirements (RNC) and nutrients availability (NAV) were small. NAV values are very close to the threshold value of RNC. The results of the qualitative analysis of the secondary compounds in the main species of plants identified in the voles diet show that the

Table 1

Percentage composition of items identified in the faecal samples of Cabrera vole in two localities of West-central Spain.

\begin{tabular}{|c|c|c|c|c|c|}
\hline \multirow[t]{2}{*}{ Item } & \multicolumn{4}{|c|}{ Moraleja (LOC1) } & \multirow{2}{*}{$\begin{array}{l}\text { P. Perales } \\
\text { (LOC2) } \\
V-82\end{array}$} \\
\hline & $\mathrm{XI}-79$ & $V-80$ & VIII-80 & $\mathrm{XII}-80$ & \\
\hline \multicolumn{6}{|l|}{ Leaves and stems } \\
\hline Gramineae & - & 21.19 & 10.63 & - & 24.18 \\
\hline Gramineae unidentif. & 62.70 & 49.62 & 47.00 & 58.39 & 45.30 \\
\hline Cistaceae & $\overline{1}$ & - & 0.74 & $\overline{00}$ & \\
\hline $\begin{array}{l}\text { Cyperaceae +Juncaceae } \\
\text { Monoco Unidentif }\end{array}$ & 14.09 & 7.85 & 17.10 & 20.87 & \\
\hline Dico. Unidentif. & - & - & $\begin{array}{l}0.74 \\
5.33\end{array}$ & $\overline{-}$ & $\overline{-}$ \\
\hline Total (leaves + stems) & 76.79 & 78.66 & 81.54 & 79.26 & 76.79 \\
\hline Seeds & 9.11 & 6.23 & - & 4.71 & 3.58 \\
\hline Unid. plants remains & 14.10 & 12.06 & 16.21 & 15.11 & 19.53 \\
\hline Insects & - & 3.05 & 2.24 & 0.92 & - \\
\hline
\end{tabular}




\section{Table 2}

Nutritional contents of more representative in the diet of Cabrera vole in West-central Spain. RNC: Recommended nutrient of diets for growth and reproduction of voles. Digestible energy $\times 1000(\mathrm{Kcal} / \mathrm{kg})$ is 2.-3.7 (Batzli, 1985). Dry matter digestibility (DMD), protein (PROT), calcium $(\mathrm{Ca})$, phosphorous $(\mathrm{P})$ and sodium $(\mathrm{Na})$ expresed as \%.

\begin{tabular}{lccccc}
\hline Genera & DMD & PROT & Ca & P & Na \\
\hline Vulpia & 62.94 & 8.42 & 0.26 & 0.22 & 0.175 \\
Poa & 60.59 & 4.88 & 0.36 & 0.16 & 0.128 \\
Bromus & 58.45 & 9.30 & 0.23 & 0.22 & 0.300 \\
Juncus sp. 1 & 52.45 & 5.32 & 0.13 & 0.03 & 0.090 \\
Juncus sp. 2 & 73.74 & 12.81 & 0.17 & 0.18 & 0.680 \\
Holoschoenus & 50.58 & 8.50 & 0.20 & 0.11 & 0.315 \\
RNC & - & $8-13$ & $0.3-0.5$ & $0.2-0.4$ & 0.020 \\
\hline
\end{tabular}

presence of the secondary compounds analyzed was very rare (only Holoschoenus gave positive saponins test). Any effects on the diet of the vole can be expected to be small or absent.

\section{DISCUSSION}

The results presented above confirm and amplify the suggestions on the feeding habits made by Ayarzaguena et al. (1976) in the same kind of patches. The main plant species observed in the faecal samples were the same species observed within the patches. Away from the patches, the plant species observed were characteristic of the agricultural areas. Unfortunately, we do not know the specific plant availability within the patches. It seems to be that the voles spent much of their time in the patches where they found and consumed the dominant plants therein (cf. Ayarzaguena et al., 1976). This apparent close relationship between the voles and their microhabitat (patches could be considered as refuges) could explain the small spatial and temporal variability observed in the diet.

When we analyzed the dominant species of plants (Gramineae) in the diet, we observed low concentrations of digestible energy and proteins. According to Batzli (1985) the vole's requirements for concentrations of protein and digestible energy are relatively low. In addition, for microtines, negative nutritional factors (other than high fibre contents) are the secondary compunds (Batzli, 1985; Bergeron, 1980; Freeland, 1974; Freeland \& Janzen, 1974). We did not find saponins, alkaloids, tannins and cyanogenic glucosides (qualitative analysis) in the samples of the dominant plants identified in the diet.

Like other vole species, the Cabrera vole can be considered to be a typical grazer. Their feeding habits (grazing on evergreen food) could 
be maintained because the temporal stability of the patches where they live was very high (Ayarzaguena et al., 1975, 1976). Likewise, there was also a high availability of green food to the voles all year round. Both patch characteristics (availability and stability) could explain the small variations observed in the diet of the Cabrera vole in the two localities of West-central Spain.

In summary the Cabrera vole diet in West-central Spain fitted the general feeding patterns of other herbivorous Microtus species described and reviewed by Batzli (1985). The conservation of this endangered species should be associated with the conservation of its microhabitat. These patches are periodically burned to improve grazing for cattle, sheep and goats (Ayarzaguena et al., 1976). Before this work was finished the habitat harbouring the vole population in LOC1 was burned. After this, the Cabrera vole population disappeared from the study plot.

Acknowledgements: The Aguilar family gave enormous lodging facilities and excellent food. Dr. Maria Manzur, Dr. G. Baztli and Dr. J. M. Bergeron and an anonymus referee considerably improved the manuscript. However, the ideas reported in this paper are the complete responsibility of the authors. The quantative chemical analyse were carried out by Dr. Balbino Garcia (C.E.B.A., C.S.I.C., Salamanca). This work was partially funded by Estacion Biológica de Doñana (C.S.I.C) and CAICYT.

\section{REFERENCES}

Ayarzaguena J., Garzón J., Castroviejo J., Ibañez C. \& Palacios F., 1975: Nuevos datos sobre la distribución de algunos micromamiferos ibéricos (Microtus arvalis, M. cabrerae, M. agrestis, Sorex araneus). Doñana Act. Vert., 2: 279-284. - Ayarzaguena J., Ibañez J. I. \& San Miguel A., 1976: Notas sobre la distribución y ecologia de Microtus cabrerae, Thomas 1906. Doñana Act. Vert., 3: 109-112. Batzli G. O., 1985: Nutrition. [In: "Biology of New World Microtus"'. R. H. Tamarin, ed.]. Spec. Publ. Amer. Soc. Mamm., 8: 779-811. - Baumgartner L. L. \& Martin A. C., 1939: Plant histology as an aid in squirrel food-habits studies. J. Wild. Manage., 3: 266-268. - Bergeron J. M., 1980: Importance des plantes toxiques dans le régime alimentaire de Microtus pennsylvanicus a deux etappes opposées de leur cycle. Can. J. Zool., 58: 2230-2238. - Cabo J. \& Pardo P., 1974: Prácticas de Farmacognosia y Farmacodinemia. Publ. Univ. Granada. Granada. - Dominguez X., 1973: Métodos de investigación fitoquimica. Limusa. Mexico. Dusi J. L., 1949: Methods for the determination of the food habits by plant microtechniques and histology and their application to cottontail rabbit food habits. J. Wildl. Manage., 13: 295-298. - Fracker S. B. \& Brischle H. A., 1944: Measuring the local distribution of Ribes. Ecology, 25: 283-303. Freeland W. J., 1974: Voles cycles: another hypotesis. Amer. Nat., 108: 238-245. - Freeland W. J. \& Janzen D. H., 1974: Strategies in herbivory by mammals: the role of plants secondary compounds. Amer. Nat., 108: 269-289. - Hansson L., 1970: Methods of morphological diet micro-analysis in rodents. Oikos, 21: 255-266. - Niethammer J. G., Niethammer G. \& Abs M., 1964: Ein Beitrag zur Kentniss der Cabreramaus (Microtus cabrerae Thomas, 1906). Bonn. Zool. Beitr., 15: 127-148. - Reichman O. J., 1975: Relation of desert rodents diet to available resources. J. Mamm., 56: 731-751. - Vericad J. R., 1970: Nouvelles données sur une espace relicte iberique: Microtus cabrerae Thomas, 1906. Mammalia, 34: 545-546. - Vericad J. R., 1971: Suncus etruscus y Microtus cabrerae en el Pirineo oscense. Pirineos, 101: 31-33. - Williams O., 1962: A technique for studying microtine food habits. J. Mamm., 43: 365-368. 